\title{
Pulmonary Management in Aluminum Phosphide Poisoning
}

Sir,

We read the review article titled, "Thoughts on the current management of acute aluminum phosphide toxicity and proposals for therapy: An evidence-based review" by Farahani et al. with great interest. ${ }^{[1]}$ Authors have well described the new treatment strategies for aluminum phosphide (ALP) poisoning including decontamination, emergency stabilization, and supportive care for cardiovascular, renal, metabolic, and electrolytes abnormalities. 
Pulmonary complications have also been described in ALP poisoning that requires aggressive support.

Acute respiratory distress syndrome (ARDS) can supervene after 6-24 hours, requiring mechanical ventilation support. ${ }^{[2,3]}$ While the benefit of corticosteroids for ARDS is not established, they might be considered in ALP poisoning as adrenocortical insufficiency is described. ${ }^{[4]}$

Pulmonary aspiration with chemical pneumonitis may occur, and secondary bacterial pneumonia requires antimicrobial therapy.

Pulmonary edema may exacerbate circulatory impairment and may require mechanical ventilation and positive end-expiratory pressure (PEEP). ${ }^{[5]}$ It may be noncardiogenic due to direct cytotoxicity and possibly small vessel injury, or there may be a cardiogenic component in some cases. It may manifest with oxygen desaturation, crackles or rales, and occasionally, pink frothy sputum.

Bronchodilators should be considered in the presence of bronchospasm with cardiac and electrolyte monitoring as arrhythmia or hypokalemia may be precipitated.

Central respiratory depression or ventilatory effort failure is rarely described but might complicate severe poisoning.

\section{Financial support and sponsorship}

Nil.

\section{Conflicts of interest}

There are no conflicts of interest.

Ashok Kumar Pannu

Department of Internal Medicine, Postgraduate Institute of Medical Education and Research,

Chandigarh, India
Address for correspondence: Dr. Ashok Kumar Pannu, Department of Internal Medicine, $4^{\text {th }}$ Floor, F Block, Postgraduate Institute of Medical Education and Research, Chandigarh - 160 012, India.

E-mail: gawaribacchi@gmail.com

\section{RefEREnCes}

1. Farahani MV, Soroosh D, Marashi SM. Thoughts on the current management of acute aluminum phosphide toxicity and proposals for therapy: An evidence-based review. Indian J Crit Care Med 2016;20:724-30.

2. Bajaj R, Wasir HS, Agarwal R, Malhotra A, Chopra P, Bhatia ML. Aluminum phosphide poisoning: Clinical toxicity and outcome in eleven intensively monitored patients. Natl Med J India 1988;1:270-4.

3. Chugh SN, Ram S, Mehta LK, Arora BB, Malhotra KC. Adult respiratory distress syndrome following aluminium phosphide ingestion. Report of 4 cases. J Assoc Physicians India 1989;37:271-2.

4. Chugh SN, Ram S, Sharma A, Arora BB, Saini AS, Malhotra KC. Adrenocortical involvement in aluminium phosphide poisoning. Indian J Med Res 1989;90:289-94.

5. Chopra JS, Kalra OP, Malik VS, Sharma R, Chandna A. Aluminium phosphide poisoning: A prospective study of 16 cases in one year. Postgrad Med J 1986;62:1113-5.

This is an open access article distributed under the terms of the Creative Commons Attribution-NonCommercial-ShareAlike 3.0 License, which allows others to remix, tweak, and build upon the work non-commercially, as long as the author is credited and the new creations are licensed under the identical terms.

\begin{tabular}{|l|l|}
\hline \multicolumn{2}{|c|}{ Access this article online } \\
\hline Quick Response Code: & Website: \\
\hline & www.ijccm.org \\
\hline
\end{tabular}

How to cite this article: Pannu AK. Pulmonary management in aluminum phosphide poisoning. Indian J Crit Care Med 2017;21:63-4.

C 2017 Indian Journal of Critical Care Medicine | Published by Wolters Kluwer - Medknow 